\title{
Možnosti využití empirických metod v (praktické) teologii ${ }^{1}$ Jana Šídlová
}

\section{Úvod}

Při provádění a interpretaci svého prvního výzkumu v oblasti empirické teologie, který se týkal zkušenosti mladých lidí se společenstvím v církvi, jsem se takřka dostala do vědecké rozpolcenosti. Moje teologické myšlení a vlastní zkušenost s církví i se zkoumaným tématem ovlivňovaly kladené otázky během rozhovorů a vstupovaly i do analýzy těchto rozhovorů. Zároveň mě paradigma metodiky výzkumu, v tomto případě fenomenologické sociologie, nutilo zcela zapomenout na svou teologii a církevní zkušenost. S podobným problémem se potýká každý teolog, který se rozhodne využít empirické metody k výzkumu tradičně teologických oblastí. Empirické metody se dají totiž využít rozličným způsobem. Holandský teolog Johannes van der Ven se pokusil tyto přístupy sjednotit a vytvořil z nich paradigmatické modely pro praktickou teologii, kterou pojímá jako empirickou. Jedná se o modely monodisciplinarity, multidisciplinarity, interdisciplinarity a intradisciplinarity. Každý model představuje určité epistemologické východisko, jak s empirickými metodami pracovat. ${ }^{2}$ Poslední model pak Van der Ven favorizuje a považuje ho za výchozí model pro své pojetí empirické teologie. Domnívám se, že empirické metody v rámci modelu intradisciplinarity nejsou využitelné pouze v praktické teologii, ale mohou se stát výzvou i pro teologii systematickou, což se pokusím obhájit $\mathrm{v}$ tomto článku. V intradisciplinárním modelu můžeme být zároveň teology i empiriky, aniž bychom se dostali do metodologického rozporu.

Nejprve představím, $v$ jakých myšlenkových horizontech by měla teologie pracovat, aby mohla využívat empirické metody, a následně představím Van der Venovy modely pro praktickou teologii. Poté se budu zabývat samotnými empirickými metodami a vysvětlím, které z těchto metod jsou pro teologii vhodné. Za výchozí bod pro další teologické zkoumání na tomto místě považuji kvalitativní metody, $\mathrm{z}$ nichž je důležitá především etnografie, kde hraje osobní pozice výzkumníka největší roli.

\section{Teologie a empirické vědy: Rozpor nebo soulad?}

Na první pohled se zdá, že teologie a empirické vědy působí ve dvou oddělených oblastech a navzájem se nepotřebují. Podle K. Skalického se teologie rodí z potřeby porozumět smyslu světa a našeho pobývání v něm. Tato potřeba je reakcí na existenciální úzkost, která je člověku v urči-

1 Tento článek je výstupem projektu specifického výzkumu GAJU č. 157/2016/H.

2 Srov. Johannes van der VEN, Practical theology: an empirical approach, Leuven: Peeters, 1998, s. 89-112. 
tých mezních situacích vlastní. K. Skalický hovoří o dvou horizontech myšlení, z nichž každý je charakterizován jednou otázkou. V prvním se můžeme ptát: „Jak musí být chápán původ světa, aby svět byl racionálně vysvětlitelný?", ve druhém se tážeme: „Jak musí být chápán původ světa, aby můj život, a život mé skupiny a vůbec všech lidí mohl mít smysl v souvislosti tohoto světa? “3 První horizont nazývá intelektualistický, druhý existenciální, přičemž tento druhý představuje výchozí bod pro jeho teologii. ${ }^{4}$ Intelektualistický horizont pozoruje svět zvenčí, z určitého hlediska jako výsek reality a je typický pro přírodní a sociální vědy s jejich empirickou metodologií. Druhý přístup se táže po smyslu, snaží se pochopit svět v jeho celku, je otevřený symbolům, hodnotám a transcendenci. $\mathrm{V}$ tomto horizontu myšlení se přirozeně nachází oblast náboženství, $\mathrm{v}$ níž je činěna zkušenost víry, která předjímá poslední smysl. Teologie jako věda se pak snaží tento smysl racionálně reflektovat. ${ }^{5}$

Lze se domnívat, že pokud ponecháme teologii jen v existenciálním horizontu racionality, výrazně jí zúžíme pole působnosti ve prospěch empirických věd. Teologické fenomény pak budou ze své perspektivy zkoumat sociologie či psychologie, př́padně religionistika. K. Skalický tuto interdisciplinaritu podporuje, jeho práce je př́íladem interdisciplinárního přístupu. ${ }^{6}$ Sociální vědy mají na toto zkoumání samozřejmě nezcizitelné právo, ale neochudíme teologii, když ji zcela oddělíme od oblasti intelektuální racionality? Není na místě jednotlivé přístupy spíše sjednocovat než dále fragmentovat? Teologie se sice rodí z potřeby hledání smyslu a porozumění, náleží však do obou horizontů. Není totiž pouze vědou o Bohu či bozích, jak by napovídal význam slova teologie. ${ }^{7}$ Pokud by tomu tak bylo, empirické zkoumání by bylo nemožné. Nekonečný a všemohoucí Bůh je nepopsatelný. Přesto v něj lze uvěrit a mít s ním skrze tuto víru osobní vztah. Právě proto je teologie vědou o vyznání a praxi křestanské víry ${ }^{8}$, skrze kterou lze následně zprostředkovaně mluvit i o transcendentním a zároveň osobním Bohu. Předmètem teologie je církví dosvědčovaná víra v sebezjevení Boha v osobě a příběhu Ježíše z Nazareta. Cílem tohoto Božího sebesdělení je, aby „lidé (měli) prostřednictvím Krista, vtěleného Slova, v Duchu svatém prrístup $k$ Otci a stali se účastnými božské přirozenosti. " Víra se uskutečňuje v člověku, církvi a v kontextu celé společnosti. Je nutné zkoumat všechny její aspekty včetně těch, které tradičně zkoumají sociální vědy. Proč by si tedy teologie nemohla vypiojčit jejich metodiku a fungovat i v rámci jejich myšlenkového horizontu? Dalším důvodem, proč na tomto místě považuji teologii za součást obou horizontů, je vztah teologických idejí a křestanské praxe. Teologie není pouze teoretická věda vzletně hovořící z výšin nad církví a světem, je to také věda o vyznání a praxi křestanské víry. Cílem teologie je snaha udržovat teorii a praxi v rovnováze. Křestanská praxe a její reflexe k sobě neodmyslitelně patří. Pro každého teologa je důležitá praxe kritické sebereflexe i reflexe praxe celé církve. Zde se opět nabízí místo pro empirické zkoumání praktické dimenze křestanské víry tak, jak se projevuje v člověku a jeho okolním světě.

3 Srov. Karel ŘíHA, Fundamentální teologie v existenciálním horizontu myšlení, Studie 122-123/1989, s. 149. Dostupné na: http:// scriptum.cz/soubory/scriptum/studie/studie_1989_122-123_ocr.pdf nebo také Karel SKALICKÝ, Po stopách neznámého Boha: náboženství a Bůh v novodobém religionistickém bádání, Praha: Aula, 1994, s. 175-176.

4 František ŠTĚCH, Fundamentální teologie a křestanská identita, in: Církev a společnost: Karlovi Skalickému k 80. narozeninám, ed. František ŠTĚCH - Roman MíČKA, České Budějovice: Jihočeská univerzita v Českých Budějovicích, Teologická fakulta, 2014 , s. 30.

5 Srov. ŘíHA, Fundamentální teologie..., s. 150.

6 Srov. ŠTĚCH, Fundamentální teologie..., s. 31; SKALICKÝ, Po stopách neznámého Boha... Pozn.: Celá tato kniha je věnována rozdílným př́stupům k náboženství v jednotlivých vědeckých oborech.

7 Srov. František ŠTĚCH, Co je teologie, in: Domov jako Most. Festschrift k padesátinám prof. Ivany Noble, Studie a texty Evangelické teologické fakulty, ed. Zdenko Š. ŠIRKA, Jihlava: Mlýn, 2016, s. 11.

8 Viz Müllerova definice z jeho učebnice dogmatiky. Gerhard Ludwig MÜLLER, Dogmatika pro studium i pastoraci, Kostelní Vydř́i: Karmelitánské nakladatelství, 2010, s. 4.

9 Tamtéž a Dei Verbum 2. 
Metody empirických věd mohou teologii zásadně obohatit o dalši horizont. V praktické teologii byl tento př́stup již před časem akceptován, empirické metody a techniky se začaly použivat pro výzkum pastorační reality. S tím jsou spojeny otázky vzájemného vztahu sociálních věd a praktické teologie. Tento vztah na teoretické a později i praktické rovině rešil holandský teolog J. van der Ven, který zároveň založil první katedru empirické teologie v evropském prostředín a sehrál velice di̊ležitou roli při zavádèní empirických metod do praktické teologie. ${ }^{11}$ Je také jedním z prvních teologů $v$ ř́mskokatolické tradici, kteři se empirickým metodám systematicky věnují. Z toho dưvodu byla do tohoto článku pojednávajícím o využití empirických metod vybrána právě jeho epistemologická východiska. Před otázku volby výzkumných východisek je postaven každý, kdo se rozhodne pro empirické zkoumání reality. Jeho modely vztahủ empirických věd a praktické teologie jsou výsledkem dlouhodobého bádání a odpovídají na většinu otázek vzájemných vztahů praktické teologie a empirických věd.

\section{Modely vztahu empirických věd a praktické teologie}

Van der Ven hovoří o čtyřech modelech vztahu praktické teologie k empirickým vědám, př́padně jejich metodám. Jedná se o modely monodisciplinarity, multidisciplinarity, interdisciplinarity a intradisciplinarity. Každý model ztělesňuje způsob, jakým se k empirickým metodám přistupuje, př́padně jakým způsobem se s nimi pracuje. Jeho modely jsou řazeny také chronologicky. Nedá se říci, že by byl, snad kromě prvního, nějaký model překonán. Van der Ven však osobně preferuje model poslední, na kterém zakládá své pojetí praktické teologie jako empirické teologie. ${ }^{12}$

\section{Monodisciplinarita}

Tento model považuje praktickou teologii za aplikovanou vědu systematické teologie a Van der Ven ho datuje do období ještě před vznikem samostatné praktické teologie. V církevní praxi vždy existovaly pomůcky, návody a doporučení, jak poznatky teologie aplikovat do praxe, a praktická teologie jako samostatná disciplína tento přístup přejímá. Ta coby univerzitní disciplína vzniká na našem území v období vlády Marie Terezie zásluhou Franze Stephana Rautenstraucha, ředitele teologické fakulty v Praze. ${ }^{13}$ Rautenstrauch, obdobně jako Schleiermacher v protestantském prostředí, osobně neuvažuje o praktické teologii jako o nějaké podřadné disciplíně. Oba naopak považují za velice důležité, aby byla pastorační praxe reflektována a neustále přibližována teorii teologie systematické (Rautenstrauch) nebo historické (Schleiermacher). Van der Ven vidí jako hlavní problém deduktivní př́istup, který monodisciplinarita implikuje. Ten spočivá v aplikaci věčných pravd na konkrétní a aktuální církevní a společenskou situaci, která by neměla být příliš složitá a heterogenní. ${ }^{14}$ Je však situace v církvi a ve společnosti v postmoderní době jednoduchá

10 Ve Spojených státech šel vývoj jiným směrem, čemuž nebude v tomto článku věnována pozornost. Viz např. VAN DER VEN, Practical theology..., s. 2-8; Nancy FRANKENBERRY, Major Themes in Empirical Theology, in: Empirical Theology: A Handbook, ed. Randolph Crump MILLER, Religious Education Press, Birmingham, Alabama, 1992, s. 340-380.

11 Někteř́ hovoři dokonce, že tato role byla paradigmatická. Srov. Richard R. OSMER, Johannes van der Ven's Contribution to the New Consensus in Practical Theology, in: Hermeneutics and empirical research in practical theology: the contribution of empirical theology by Johannes A. van der Ven, ed. C. A. M. HERMANS - Mary Elizabeth MOORE, Boston: Brill, 2004, s. 149.

12 Modely jsou zpracovány podle J. van der Vena, v našem prostředí je ve zkrácené podobě cituje A. Křištan. Viz Alois KŘIŠŤAN, Vztah pastorální teologie ke společenským vědám, in: Fórum pastorálních teologů, ed. Pavel AMBROS, Velehrad: Refugium Velehrad-Roma, 2000 a VEN, Practical theology..., s. 89-112.

13 Praktická teologie na našem území vzniká pod názvem pastorální teologie. Srov. Alois KŘIŠŤAN, Počátky pastorální teologie v českých zemích, Praha: Triton, 2004, s. 26.

14 Deduktivní př́stup je zdá být překonaným i v oblasti náboženské pedagogiky, kde také dlouhodobě dominoval. Srov. Ludmila MUCHOVÁ, Budete mými svědky: dialogické rozvijení křestanské identity ve světonázorově pluralitní společnosti - pedagogická výzva, 
a homogenní? Vždyt’ je to právě naopak - jednou z charakteristik současné společnosti je její různost a nejednoznačnost. ${ }^{15}$ Složitost církevní a společenské situace se projevuje zejména v procesu církevní diverzifikace a sekularizace. Tyto dva fenomény představují další důvody, proč je třeba model monodisciplinarity jako takový odmítnout.

„Je nevyhnutelným závěrem, že za současné situace nemůže existovat jeden standardní model, jak teologické pravdy aplikovat do praxe. Protože současná sociální, církevní a pastorální situace není uniformní. Proto je třeba zavrhnout deduktivní přístup, který v sobě obsahuje koncept aplikované teologie. Ta potřebuje induktivní př́istup do současné mnohoznačné, mnohotvárné až chaotické situace na poli společnosti i církví. “16

\section{Multidisciplinarita}

Po nutnosti metodologicky přesného popisu konkrétní pastorální situace v církvi a společnosti volají od šedesátých let mnozí teologové osvobození, ${ }^{17}$ ale třeba také E. Schillebeeckx. Praktická teologie by podle nich měla převzít výsledky empirických výzkumů prováděných v sociálních vědách a dodat jim teologický vhled a interpretaci. Tento př́stup v sobě tedy zahrnuje dvoufázový proces. V první fázi teolog sbírá výsledky empirických výzkumů vztahujících se k jeho praktickému tématu a ve druhé tato data reflektuje, snaží se je vztáhnout k vhodným teologickým kritériím a shrnout z normativně-teologické perspektivy. V českém prostředí mưže být příkladem tohoto př́stupu práce Michaela Martinka Ztracená generace. Autor se v ní pokouší o teologickou interpretaci sociologických a částečně i psychologických výzkumů realizovaných na české mládeži. Pro interpretaci používá prakticko-teologická kritéria a navrhuje konkrétní pastorační řešení popisovaných situací a jevů. ${ }^{18}$

Použití tohoto je obhajováno i v německé Handbuch der Pastoraltheologie (1964). ${ }^{19}$ Rahner zavádí termín „pomocné vědy“, čímž má na mysli vědy sociální. Ty jsou podle něj beze zbytku podřízeny teologii. Je relevantní a důležité si brát sociální vědy na pomoc, protože teologie nemá pro empirickou analýzu praxe metody vlastní a není ani kompetentní takové metody vytvářet. Pro potřeby teologie je tedy na místě užití metod sociálních věd. I přesto však Van der Ven konstatuje, že vztah teologie a empirických věd je v Rahnerově manuálu pastorální teologie nedostatečně teoreticky definován. To se projevuje například tím, že neuvažuje o případných nevýhodách svého pojetí. Van der Venovi námitky proti Rahnerovu pojetí vztahu empirických věd a teologie můžeme shrnout následujícím způsobem:

1. Podle Rahnera je teologie absolutně nadřazena empirickým vědám, přesto na jejich výzkumech zcela závisí. Výzkumných materiálů od empirických věd pro použití v praktické teologii také není dostatek. Výzkum církevního prostředí totiž výzkumníky v oblasti sociálních věd př́liš neláká. ${ }^{20}$

Brno: Kartuziánské nakladatelství a vydavatelství, 2011, s. 115-119.

15 Srov. Aleš OPATRNÝ, Pastorace v postmoderní společnosti, Kostelní Vydř́í: Karmelitánské nakladatelství, 2001 a Aleš OPATRNÝ, Cesty pastorace v pluralitní společnosti, Kostelní Vydří: Karmelitánské nakladatelství, 2006.

16 VAN DER VEN, Practical theology..., s. 92-93.

17 Srov. Rosino GIBELLINI, Teologické směry 20. století, Kostelní Vydř́: Karmelitánské nakladatelství, 2011, s. 365-394.

18 Srov. Michael MARTINEK, Ztracená generace? O duchovním dialogu mezi českou mládeží a katolickou církví, Svitavy: Trinitas, 2006.

19 Viz 5. díl Handbuch der Pastoraltheologie (1964). Karl RAHNER, Lexikon der Pastoraltheologie: Handbuch der Pastoraltheologie: praktische Theologie der Kirche in ihrer Gegenwart, Freiburg im Breisgau: Herder, 1972.

20 Van der Ven hovoří o situaci v Nizozemí, u nás je však snad ještě horší. Sociologie náboženství v České republice není v uspokojivém stavu. Zdeněk R. Nešpor hovoří dokonce o tom, že není zcela etablovaná. Srov. Zdeněk R. NEŠPOR, Ne/náboženské naděje intelektuálů: 
Navíc se tito výzkumníci v teologických termínech orientují jen s velkými obtížemi, a proto může být teologická intepretace výsledků práce neteologů značně problematická.

2. Není jasné, z jaké teologické perspektivy by měla být vedena interpretace výzkumů. Handbuch der Pastoraltheologie preferuje dějiny spásy, Van der Ven však namítá, že toto kritérium je přiliš abstraktní a není vůbec vysvětleno, jak by mělo být propojeno s konkrétními problémy a potřebami lidí v církvi. Nedají se najít v církevní praxi a lidské zkušenosti víry nějaká zcela jiná kritéria?

3. Problematický je samotný, Rahnerem navrhovaný, dvoufázový proces, který lze těžko vyvážit, když pracuje se zcela odlišnými kategoriemi.

S jakými kategoriemi pracují empirické vědy? Jako příklad bych zde chtěla ukázat kategorie z oblasti sociologie. Ta předpokládá určitou filosofii (nebo sociologickou teorii), která pak významně ovlivňuje sociologovo vnímání a hodnocení reality. Z důvodů výrazné odlišnosti jednotlivých sociologických perspektiv byl za př́klad vybrán pohled strukturálního funkcionalismu. ${ }^{21}$ Podle něj je církev založena na ustálených společenských normách a ne/formálních sankcích a má svou funkci v rámci celé společnosti. Úspěšné naplnění této funkce směruje společnost $\mathrm{k}$ hlubší integraci. Jakožto prvek struktury společnosti je církev ovlivněna a ovlivňována vazbami, které má. Podle Talcota Parsonse a jeho AGIL modelu má církev čtyři subsystémy či funkce: adaptace, dosahování cílů, integrace, udržení latentních vzorců. ${ }^{22}$ Adaptace v sobě zahrnuje přizpůsobení se možnostem a opatřování zdrojů z prostředí. Dosahování cílů značí i usměrnění zdrojů k dosažení cílů a určování priorit. Aby byla církev soudržná a směřovala v cíli, reguluje vztahy uvnitř systému pomocí norem. K tomu pak potřebuje motivovat aktéry k výkonu rolí nezbytných pro systém a dále řídicí mechanismus pro udržení napětí v systému. Na vyšší úrovni, tedy na úrovni společenského systému jako celku, plní náboženství a církve funkci udržení vzorců. Změnou jednoho prvku struktury se mění celá struktura, včetně církve a jejích vazeb. Na př́kladu strukturálního funkcionalismu se dá zřetelně ukázat propastný rozdíl mezi sociologickou a teologickou teorií církve. Van der Ven si tuto propast uvědomuje a volá po změně prrístupu, kterou nabídnou následující modely.

\section{Interdisciplinarita}

Tento přístup, na rozdíl od přístupu předchozího, předpokládá interakci, vztah a spolupráci mezi oběma obory - nejen pouhé existování vedle sebe. Příklon $\mathrm{k}$ interdisciplinaritě mezi praktickou teologií a sociálními vědami naznačuje i pátý díl německé pastorální teologie Lexikon der Pastoraltheologie (1972) kde se volá po rozvoji tohoto přístupu. Interdisciplinarita může být dvojího druhu:

vývoj české sociologie náboženství v mezinárodním a interdisciplinárním kontextu, Dolní Břežany: Scriptorium, 2008, s. 368-376. Kromě pravidelného sčítání obyvatel, které přináší statistické výsledky o klesajícím počtu věrících největších českých církví, jsou u nás pravidelně realizovány výzkumy EVS a ISSP. Analýzu kvantitativních výzkumů náboženství v České republice provedla např. Dana Hamplová ve své publikaci Dana HAMPLOVÁ, Náboženství v české společnosti na prahu 3. tisíciletí, Praha: Karolinum, 2013. V oblasti kvalitativních metod představují výjimku dvě velmi kvalitní a detailní práce J. Váněho a B. Spalové. Jan VÁNĚ, Komunita jako nová naděje?: náboženské (ne)institucionalizované komunity z pohledu sociologie náboženství, Plzeň: Západočeská univerzita v Plzni, 2012 a Barbora SPALOVÁ, Bůh ví, proč: studie pamètí a režimů moci v křestanských církvích v severních Čechách, Brno: Centrum pro studium demokracie a kultury, 2012.

21 Zpracováno podle Émile DURKHEIM, Elementární formy náboženského života: systém totemismu v Austrálii, Praha: OIKOYMENH, 2002; Talcott PARSONS, Společnosti: vývojové a srovnávací hodnocení, Praha: Svoboda, 1971 a Daniel L. PALS, Osm teorií náboženství, Praha: ExOriente, 2015.

22 Srov. Zdeněk R. NEŠPOR - David VÁCLAVÍK, Příručka sociologie náboženství, Praha: Sociologické nakladatelství SLON, 2008 , s. 65. 
1. teolog je zároveň sociologem;

2. teologové se sociology vzájemně spolupracují.

Zásadní výhodou tohoto modelu je, že pokud se opravdu podaří konstruktivní dialog mezi teologickými a empirickými obory, jsou výsledky společně realizovaných studií přijatelné a relevantní pro obě strany. V současné době je interdisciplinarita dominantním př́ístupem $\mathrm{v}$ německém prostředí. ${ }^{23} \mathrm{~V}$ našem kontextu může být příkladem interdisciplinárního přístupu například habilitační práce Michala Kaplánka. Ten prováděl kvalitativní výzkum formou tematických rozhovorů s konvertity. Na jejich základě pak zhodnocuje motivaci mladých lidí pro vstup do katolické církve a navrhuje pastorační priority v dané oblasti. ${ }^{24}$ Van der Ven však interdisciplinaritu nefavorizuje a vidí v ní zásadní problém. Teologie a sociologie jsou založeny na odlišných paradigmatech a používají jiné metody. Kterým tedy dá vědec teolog a zároveň sociolog přednost? Neupadne do vědecké rozpolcenosti? Pokud se jedná o spolupráci mezi více odborníky, je možné nastavit skutečnou rovnováhu a vést produktivní dialog v rámci výzkumné skupiny? Jsou teologové schopni respektovat sociologické paradigma a sociologové paradigma teologické? Jsou teologové schopni unést zdrcující kritiku ze strany sociologů a budou sociologové naslouchat teologům, když to byla právě teologie (a filosofie), od které se sociální vědy emancipovaly? Zdá se, že mnozí sociologové již jasně naznačili, že se bez teologie obejdou. ${ }^{25}$

„Pokusy ustanovit dialog s teologií a současnými sociálními vědami končí nerovným rozložením sil, bez ohledu na to, co si o tom kdo myslí. Důvodem je, že sociální vědy nepotřebují teologii ke své činnosti, zatímco praktická teologie, minimálně v interdisciplinárním modelu, se bez nich neobejde. ${ }^{\text {26 }}$

\section{Intradisciplinarita}

Model intradisciplinarity považuje Van der Ven za nejlepší řešení pro vztah praktické teologie a sociálních věd. Intradisciplinarita implikuje využití metod a technik jednoho oboru v jiném, což se ve vědách při jejich vývoji běžně děje. Není právě teologie vědou, která vždy reagovala na dobové metodologické trendy nebo je dokonce svého času diktovala? Není tedy ideální čas pro adopci empirických metod? Zůstane při tom však teologie stále teologií? Van der Ven tvrdí, že ano a udává pro to několik důvodů. Využití empirických metod je adekvátní, protože hlavním objektem teologie není Bůh, ale lidská zkušenost s ním. ${ }^{27}$ Pokud by byl přímým objektem teologie Bůh, bylo by využití empirických metod nemožné. Bůh, který se zjevuje, je podle Van der Vena částečně poznatelný pouze skrze víru, skrze lidskou zkušenost s Ním. Tato zkušenost je jak individuální, tak společenská jako zkušenost společenství církve, která se určitým způsobem odráží $\mathrm{v}$ její tradici. Je přijatelné tuto zkušenost zkoumat empiricky, protože je veskrze lidská, zároveň

23 Interdisciplinární přístup používají např. P. M. Zuhlener, H. G. Zieberts či T. Faix. Zuhlener je spoluautorem výzkumů EVS. H. G. Zieberts viz Hans-Georg ZIEBERTZ, Imagining God: empirical explorations from an international perspective, Münster: LIT, 2001.

24 Zkrácená verze habilitační práce v němčině formou odborného článku viz Michal KAPLÂNEK, Rozhodnutí mladého člověka nechat se pokřtít v katolické církvi, in: Konverze a konvertité: sborník z mezioborového semináre o problematice náboženského obrácení, ed. Ivana NOBLE - Jiří HANUŠ, Brno: Centrum pro studium demokracie a kultury, 2009, s. 81-110.

27 Např. Ivana NOBLE, Po božích stopách: teologie jako interpretace náboženské zkušenosti, Brno: Centrum pro studium demokracie a kultury, 2004; Leonardo BOFF - Clodovis BOFF, Introducing liberation theology, London: Burns \& Oates, 2000 či Paul TILLICH, Lidské tázání po nepodmínèném, Brno: 3K, 1997. 
je možno využít i dalších metod z jiných odvětví teologie. Teologie není v otázce metod jednotná. Metody se sdružují do jednotlivých metodologických rodin, které sdílejí shodné premisy a argumentační postupy. Samotná klasifikace teologických metod se pak stává složitým problémem pro jejich velké množství, R. Haight hovoří dokonce o typologii typologií teologických metod $^{28}$. Je tedy na subjektivním posouzení teologa, jaké metody se rozhodne pro svou práci použít. Van der Ven preferuje intradisciplinaritu, protože podle něj řeší problémy modelů předchozích. R. R. Ganzevoort však namítá, že tento model může vést $\mathrm{k}$ izolaci praktické teologie podobně jako model monodisciplinarity, protože nenastoluje dialog se sociálními vědami. ${ }^{29}$

Van der Ven považuje praktickou teologii za hermeneuticko-komunikativní praxi, která se snaží neustálou komunikací překlenout propast mezi tradicí a současností. Je zde výrazný vliv Habermasovy etiky, která je korigována konceptem Božího království ${ }^{30}$ Tradici lze zkoumat literárně-kritickou či historickou metodou. Pro zkoumání současnosti se pak zdají být ideální empirické metody, které byly vytvořeny jako nástroj sociálních věd právě pro zkoumání člověka a jeho zkušenosti ve světě. Opět je třeba zopakovat, že pro praktickou teologii toto nepředstavuje žádný problém. Jde jen o to, jakým zpo̊sobem bude s metodami zacházet. Empirické metody představují výzvu i pro další oblasti teologie. Za příklad mohou posloužit teologické pojmy sensus fidelium a consensus fidelium ${ }^{31}$, které se přímo nabízejí k empirickému zkoumání. Cit věřícího pro věci víry je vskutku krásný teologický koncept, ale čemu skutečně věřící věří? Věří tradovanému učení církve, nebo ve své vlastní křestanské praxi objevují nové teologické myšlenky? Možná pak teologické koncepty a teorie vzešlé z toho zkoumání budou pro věřící srozumitelnější a mohou přiblížit akademickou teologii psanou od stolu širšímu okruhu věřících. Jsou však skutečně teologické koncepty a teorie měřitelné? Van der Ven tvrdí, že ano. Teologie tradičně používá analogie a modely pro výklad svých pojmů, ty pak mohou být pomocí pečlivé operacionalizace použity ve výzkumu. Van der Ven preferuje smíšenou podobu výzkumu a navrhuje metodu empiricko-teologického kruhu, která v sobě zahrnuje stanovení problému a cíle, indukci, dedukci, samotné testování a evaluaci výsledků. Výsledky těchto výzkumů nepředstavují teologické teorie, ale jsou příspěvkem do hermeneuticko-komunikativní praxe církve, jsou snahou o její (sebe) pochopení a vylepšení.

Byly činěny pokusy srovnávat Van der Venův empiricko-teologický kruh s pastorálním kruhem, konceptem vzešlým z teologie osvobození v latinsko-americkém prostředí. Pastorální kruh je vylepšeným konceptem Cardinjovy metody vidět-posoudit-jednat, která byla v římskokatolické tradici akceptována její aplikací v encyklice Mater et Magistra. ${ }^{32} \mathrm{~V}$ pastorálním kruhu jsou jednotlivé kroky následující: zkušenost (vidět), sociální analýza a teologická reflexe včetně modlitby (posoudit) a pastorační jednání (jednat). ${ }^{33} \mathrm{~V}$ britském prostředí pak ve své praktické teologii pastorální kruh používají P. Ballard a J. Pritchard ${ }^{34}$ a právě jejich koncept srovnává M. J. Cartledge ${ }^{35}$ s Van der

28 Srov. Roger HAIGHT, Critical Witness: The Question of Method, in: Faithful Witness. Foundations of Theology for Today's Church, ed. Leo J. O'DONOVAN - T. Howland SANKS, New York: Crossroad, 1989, s. 188.

29 Srov. R. Ruard GANZEVOORT, Van der Ven's Empirical/Practical Theology, in: ed. C. A. M. HERMANS - Mary Elizabeth MOORE, Hermeneutics and empirical research in practical theology: the contribution of empirical theology by Johannes A. van der Ven, Boston: Brill, 2004, s. 63.

30 Srov. VAN DER VEN, Practical theology..., s. 59-73 a OSMER, Johannes van der Ven Contribution to the New Consensus in Practical Theology, s. 155.

31 LG 12.

32 Viz Mater et Magistra, čl. 236.

33 Srov. Joe HOLLAND - Petr L. HENRIOT, Social analysis: linking faith and justice, Maryknoll, N.Y.: Orbis Books, 1983.

34 Paul BALLARD - John PRITCHARD, Practical Theology in Action: Christian Thinking in the Service of the Chruch and Society, London: SPCK, 1996.

35 Srov. Mark J. CARTLEDGE, Practical Tehology and Empirical Identity, EuroJTh, 1998, 7:1, s. 37-44. Viz. https://biblicalstudies.org.uk/ pdf/ejt/07-1_037.pdf. 
Venovým empiricko-teologickým kruhem. Jedná se však o srovnávání nesrovnatelného. Pastorální kruh je $\mathrm{v}$ první řadě praktickým nástrojem pro řešení problémů $\mathrm{v}$ pastorační službě církve (např. v církevním společenství). Nemá žádnou propracovanou empirickou metodologii a ani ji nepotřebuje. Analýza probíhá formou diskuze a modlitby zúčastněných. Van der Venova metoda empiricko-teologického kruhu je v první řadě metodologickým návodem pro provádění empiricko-teologických výzkumů v praktické teologii, nikoli pastorační pomůckou pro společenství.

\title{
Kvantitativně nebo kvalitativně?
}

Van der Venovu metodu empiricko-teologického kruhu lze zařadit do smíšeného prŕstupu, protože pracuje s kvantitativními i kvalitativními metodami. Obsahuje indukci i dedukci. V empirické teologii se však $\mathrm{v}$ jejích různých podobách používají tyto přístupy i odděleně. Jaký je mezi nimi rozdíl? K jakým výsledkům vedou? Nejdříve je třeba definovat oba př́stupy v paradigmatu empirické metodologie, posléze bude představena situace v teoretické oblasti empirické teologie.

\section{Oblast sociálních a humanitních věd}

\begin{abstract}
„Kvantitativní prrístupy $\mathrm{k}$ výzkumu v sociálních vědách v mnohém napodobují metodologii př́rodních věd. Předpokládá se, že lidské chování můžeme do jisté míry měřit a předpovídat. Kvantitativní výzkum využívá náhodné výběry, experimenty a silně strukturovaný sběr pomocí testů, dotazníků nebo pozorování. Konstruované koncepty zjištujeme pomocí měření, v dalším kroku získaná data analyzujeme statistickými metodami s cílem je zkoumat, popisovat, př́padně ověřovat pravdivost našich představ o vztahu sledovaných proměnných. ${ }^{\text {“36 }}$
\end{abstract}

Kvantitativní výzkum lze zjednodušeně charakterizovat jako ověřování hypotéz, které výzkumník deduktivně vyvodí z určité teorie. Používá se zde operacionalizace pro převedení hypotéz do měřitelné formy. Měření probíhá nejčastěji formou nějakého testu či dotazování, v závěru se hypotézy testují a výsledek se vztahuje zpět $\mathrm{k}$ teoriii. ${ }^{37}$ Důležitá je reprezentativnost vybraného vzorku, reliabilita a validita. Výsledky těchto výzkumů lze zobecnit na populaci, jsou relativně nezávislé na výzkumníkovi a poskytují vcelku přesná data.

Kvalitativní výzkum byl zpočátku vnímán jako jakýsi doplněk předchozího př́stupu, v současné době je však spíše rovnocenným partnerem. Pracuje se zde spíše induktivní metodou a neexistuje pouze jediný možný způsob, jak kvalitativní výzkum provádět. ${ }^{38}$ Většinou však na začátku tohoto výzkumu stojí téma a výzkumná otázka, podle ní pak výzkumník vyhledává a analyzuje veškeré informace, které se k otázce vztahují. Výzkumník často pracuje v terénu, je př́mou součástí výzkumu. Výzkum má dlouhodobější charakter, zachází se více do hloubky, ideálně tam, kam až to jde. Analýza dat a jejich sběr probíhá současně. Výsledky těchto výzkumů nelze zobecňovat, jsou spíše sondou do vybraného problému, pomáhají jeho teoretickému porozumění. Vzhledem k cíli

36 Jan HENDL, Kvalitativní výzkum: základní teorie, metody a aplikace, Praha: Portál, 2012, s. 44.

37 Srov. HENDL, Kvalitativní výzkum..., s. 44.

38 J. Hendl používá klasifikaci kvalitativních přístupů od L. Spencera. Ten jmenuje jednotlivé tradice kvalitativního výzkumu, které se rozvinuly $\mathrm{v}$ různých sociálních či humanitních vědách. Jsou to: etnografie, fenomenologie/entometodologie, konverzační analýza, diskurzní analýza, protokolární analýza, zakotvená teorie, konstruktivismus, kritická teorie a ekologická psychologie. Zároveň však upozorňuje na to, že se stále objevují nové a aktuální prrístupy. Srov. HENDL, Kvalitativní výzkum..., s. 52. 
takového výzkumu není reliabilita tak důležitá jako u kvantitativního výzkumu, naopak validita je výrazně vyšší.

V současné době se oba přístupy považují víceméně za komplementární a často se realizují smíšené výzkumy pomocí obou technik. Přesto se najdou vědci, kteří považují kvalitativní přístup za málo vědecký, a naopak výzkumníci, kteří opovrhují kvantitativním přístupem jako nevhodným pro zkoumání člověka. ${ }^{39}$ Jaká je situace v empirické teologii?

\section{Oblast empirické teologie}

V empirické teologii jako takové existují výzkumy kvantitativní, kvalitativní i smíšené. Z počátku, obdobně jako v sociologii, převládaly výzkumy kvantitativní ${ }^{40}$, později se rozšśřil i druhý přístup. Kvalitativní přístupy jsou nejčastěji etnografické, či přijímají formu zakotvené teorie ${ }^{41}$. Smíšenou metodu pak preferuje Van der Ven a dává jí formu již zmiňovaného empiricko-teologického kruhu. Kvantitativní metoda obsahuje přesná data, její výsledky lze zobecňovat a nálezy mohou představovat skutečnou výzvu pro teologii, právě pro jejich reprezentativnost. Ukazují-li výsledky sčítání obyvatel klesající počty členů církve nebo výzkumy EVS neznalost křestanských hodnot (i u „papírových“ členů církve), je to pro církev problém, který je třeba řešit. Kvantitativní výzkum se však nemůže dostat do hloubky. Nesdělí, proč lidé od církve odcházejí, kam odcházejí a co si o církvi skutečně myslí. Hlubiny víry nemohou být kvantifikovány. Zároveň zde není dostatečný prostor pro působení teologie ve výzkumu jako takovém. Výzkumník se snaží o co největší odstup a objektivitu, jeho působení ovlivňuje maximálně výběr tématu, výzkum probíhá většinou bez bezprostřední interakce se zkoumaným vzorkem. Lze se domnívat, že výzkumník potřebuje být teologem jen pro teologicky správnou operacionalizaci hypotéz a analýzu výsledků. Kvantitativní př́stup proto může velice dobře fungovat v modelu multidisciplinarity a interdisciplinarity. Domnívám se, že pro potřeby teologie vyžaduje kombinaci s kvalitativním př́istupem. Ten je svou povahou otevřen pro přímou účast výzkumníka s filosofií nebo vírou, kterou on osobně vyznává. Je zde často přímá interakce mezi výzkumníkem a zkoumaným. Zdá se být tedy pro využití v teologii vhodnější. Jeho závěry však lze zobecňovat jen s velkou opatrností a může být realizován většinou jen na mikroúrovni. Zdá se tedy, že i v empirické teologii se jeden př́stup neobjede bez druhého a vzájemně se mohou dobře vyvažovat. Co k tomu říkají sami empiričtí teologové? Nejdřive je třeba poukázat na vztah kvantitativního a kvalitativního př́istupu. K tomu poslouží analýza prŕístupu Jaco S. Dreyera. Posléze představíme etnografii jako specifický empiricko-teologický př́stup v pojetí Pete Warda a jeho kolegů z platformy Ecclesiology and Etnography. ${ }^{42}$

\section{Odstup nebo účast?}

Zajímavou perspektivu do vztahu mezi kvantitativním a kvalitativním přístupem vnáší Jaco S. Dreyer $^{43}$. Ten poukazuje na převládající dichotomii mezi oběma př́stupy a $\mathrm{k}$ překonání tohoto

39 Srov. HENDL, Kvalitativní výzkum..., s. 54-62.

40 Viz např. jedna z prvních kolektivních publikací v oblasti empirické teologie od H. G. Ziebertze, která je pokusem představit realizované kvantitativní výzkumy v mezinárodní perspektivě. Pojem empirická teologie je zde chápán podstatně šířji, než jak ho chápe Van der Ven, i jako sociologické zkoumání teologických otázek. Viz. Hans-Georg ZIEBERTZ, Imagining God: empirical explorations from an international perspective, Münster: LIT, 2001.

41 Srov. Peter NÁKAČKA, Grounded theory a možnosti jej využitia v oblasti praktickej teologie, Teologický časopis: Fórum pro krestanský dialóg 1/2016, s. 83.

42 Platforma Ecclesiology and Etnography sdružuje od roku 2007 akademiky zabývající se teologickým a empirickým studiem křestanských církví v ekumenickém duchu. Viz: http://www.ecclesiologyandethnography.com/.

43 Viz Jaco S. DEYRER, Establishing truth from participation and distanciation in empirical theology, in: Empirical theology in texts and 
rozporu si bere na pomoc hermeneutiku Paula Ricoeura. Ricoeur ve svém eseji o vztahu vědy a ideologie ${ }^{44}$ upozorňuje, že pokud chceme porozumět fungování společnosti (jejím vztahům, kulturní tradici a historii), nastává dialektické napětí mezi naší relativní autonomií (odstupem) vůči těmto jevům a zároveň naší účastí, kterou nelze jen tak odstřihnout. Chceme-li posléze při našem hledání tohoto porozumění minimalizovat ideologické vlivy, je třeba využít tohoto napětí $\mathrm{v}$ rámci hermeneutického pátrání po pravdě. Dreyer tento předpoklad přijímá a vztahuje $\mathrm{k}$ hlavním empirickým př́stupům - kvantitativní výzkum charakterizuje právě odstupem a kvalitativní účastí.

„Sám vědec se tedy musí ponořit do světa těch, které zkoumá (účast), aby jejich hlasy nebyly přehlušeny vědcovou interpretací. Toto předpokládá kvalitativní prístup. Na druhou stranu je cílem i opačný postup, a to eliminovat ideologické interpretace zkoumaných, což lze jedině odstupem, který implikuje kvantitativní prístup. “45

V empirickém výzkumu pojem účast referuje $\mathrm{k}$ naší situovanosti ve světě, $\mathrm{k}$ našemu setkání s ostatními a s jejich vlastní minulosti a brání nám násilně vtlačovat zkušenost ostatních do předem připravených konceptů a schémat. Odstup je základem vědeckého př́stupu a zahrnuje v sobě snahu o objektivitu, kritické myšlení, konceptualizaci, srovnávání a další. Každý výzkumník musí být schopen kriticky hodnotit vlastní kulturní, ekonomické, sociální a politické pozice, čehož může dosáhnout právě odstupem. Dreyer argumentuje, že určitá míra odstupu a účasti je prrítomna $\mathrm{v}$ obou př́stupech, proto se nejedná o diametrálně odlišné cesty $\mathrm{k}$ porozumění skutečnosti. Napětí mezi odstupem a účastí chrání z pohledu Ricoeurovy hermeneutiky vědu před tím, aby se nestala ideologií. $\mathrm{V}$ kvantitativním prístupu je třeba obzvlášt dávat pozor na to, aby odstup nepřevládl nad účastí, v kvalitativním př́stupu je tomu naopak. Plodné napětí mezi oběma přispívá $\mathrm{k}$ pravdivému porozumění. Toto napětí pak zajistí umění reflexivity, tak jak jí charakterizuje Pierre Bourdieu ${ }^{46}$. Reflektovat je třeba vlastní předsudky i vlastní vědeckou komunitu a její metody. To je pro empirického teologa práce na celý život. Výraz reflexivita je i základem praktické teologie P. Warda. Teolog - výzkumník reflektuje své osobní, společenské i kulturní kontexty při výzkumu, který provádí. Tyto kontexty ovlivňují nejen to, co je zkoumáno, ale i způsob provádění výzkumu samotného. ${ }^{47}$ Reflexivitu vyžaduje ve velké míre etnografický př́istup, na který se ted’ zaměŕíme.

\section{Etnografie jako reflexivní teologie}

Etnografie se řadí ke kvalitativním výzkumným technikám a předpokládá př́mou účast pozorovatele na zkoumaných jevech. Tradičně se využívala s cílem získat celkový obraz určité společenské skupiny, původně např̀. kmene žijícího někde na odlehlém místě světa. Využívá převážně různé druhy pozorování a rozhovory se zkoumanými jedinci či skupinami. Jsou zkoumány perspektivy

tables: qualitative, quantitative and comparative perspectives, ed. Leslie J. FRANCIS - Mandy ROBBINS - Jeff ASTLEY, Boston: Brill, 2009, s. 3-25.

44 Paul RICOEUR, From Text to Action: essays in hermeneutics II, London: Athlone Press, 1991, s. 258-269, citováno podle DEYRER, Establishing..., s. 7-8.

45 DEYRER, Establishing..., s. 9

46 Srov. Pierre BOURDIEU, Science of Science and Reflexivity, Chigaco: University of Chicago Press, 2004, citováno podle DEYRER, Establishing..., s. 20-23.

47 Pete WARD, Participation and Mediation: A Practical Theology for the Liquid Church, London: SCM Press, 2008 , s. 3. 
členů skupiny, obsahy a formy jejich myšlení, interakce a sociální praktiky. Jde o popis určité skupiny jako celku včetně jejích částí a vztahů mezi nimi. ${ }^{48} \mathrm{~V}$ současné době se pod pojem etnografie zahrnuje celá řada př́stupů $\mathrm{z}$ různých disciplín, pro které jsou důležité tyto prvky: participace, vnoření se, reflexe, reflexivita, reprezentace, detailní popis, porozumění etickým principům skupiny, zplnomocnění (empowerment) a porozumění jako takové. ${ }^{49}$ Etnografie se na první pohled zdá být vhodným nástrojem pro teologii, obzvlášt pro zkoumání církevní praxe. Pete Ward se domnívá, že pokud chceme skutečně porozumět církvi, musíme uznat, že je zároveň teologickou a zároveň sociálně-kulturní realitou. Je tedy třeba využít jak teologické, tak sociologické prostředky pro zkoumání této reality.

„Vyžaduje to neustálou interakci mezi teoriemi a principy odvozenými z teologické tradice a obezřetné účastné pozorování jednotlivých aspektů církevní situace. Teologická zobecnění budou ovlivněna tímto pozorováním, užívajíce metody sociálního a kulturního výzkumu, ale toto pozorování je v zásadě teologické.“50

Využívání empirických metod lze zdůvodnit čistě teologicky. Paul S. Fiddes argumentuje trinitárně. ${ }^{51}$ Teologie podle něj předpokládá, že žijeme ve světě, kde se trojjediný Bůh (sebe)zjevuje. Tento Bůh nemůže být objektivně pozorován jako ostatní věci ve světě, je poznáván odlišným zpơsobem, tedy přesněji účastí na jeho lásce, kterou jsou propojeny jednotlivé Božské osoby v Trojici. Když se ve světě angažujeme ve společenství vzájemnosti a láskyplných vztahů, které jsou hlubší a bohatší, než bychom si sami dokázali představit, než bychom sami dokázali vytvořit, poznáváme hlouběji trojjediného Boha. Mimo Boha není nic, plně se manifestuje ve světě a pouze z něj ho můžeme poznávat. V oblasti ekleziologie (či praktické teologie) toto platí dvojnásob, zde se Boží působení přímo předpokládá! Musíme však odmítnout dědictví racionalismu, který svět rozlišuje na subjekt a objekt. Musíme poznávat svou účastí, která je podstatou etnografického př́stupu.

Pro etnografii argumentuje i John Swinton. ${ }^{52}$ Ten, obdobně jako Van der Ven, odmítá využívat sociologické metody při zkoumání teologických fenoménů stejným způsobem jako sociologové. Argumentuje, že tyto metody mají v pozadí skrytou neteologickou perspektivu. Pro etnografii je touto perspektivou zejména fenomenologie či naturalismus. ${ }^{53}$ Hlavním výzkumným nástrojem je však v tomto přístupu výzkumník samotný, ten je ale také teologem a pravděpodobně i členem církve, kterou hodlá zkoumat. Proč by se na ní měl zrovna on dívat jako psycholog nebo socio$\log$ ? Kromě procesu pozorování je pro etnografii nejdůležitější proces interpretace. Ten můžeme vnímat jako pokus o maximální objektivitu, což se zdá být nemožné, nebo právě naopak, jak to činí Hans G. Gadamer, který ve své hermeneutice předpokládá před-porozumění. Subjektivní a objektivní jsou spojeny dohromady v jednom kulturním a sociálním kontextu. ${ }^{54}$ Teolog může zahrnout svou teologii do etnografie jak při pozorování, tak př́i interpretaci, což vyžaduje již několikrát zmiňovanou reflexivitu. O té tvrdí, že je „způsobem poznávání, který snaží kreativně

48 Srov. HENDL, Kvalitativní výzkum..., s. 115-116.

49 Srov. Julie SCOTT-JONES - Sal WATT, Enthography: Principles into Practice, London: Routledge, 2007, s. 1, citováno podle Pete WARD, Perspectives on ecclesiology and ethnography, Grand Rapids, Mich.: W. B. Eerdmans Pub. Co., 2012, s. 6.

50 WARD, Perspectives on ecclesiology and ethnography, s. 2.

51 Paul S. FIDDES, Ecclesiology and Etnography: Two disciplines, two worlds?, in: WARD, Perspectives on ecclesiology and ethnography, s. $13-36$.

52 Srov. John SWINTON, Where is your Church?, in: WARD, Perspectives on ecclesiology and ethnography, s. 71-92.

53 Podrobný rozbor těchto sociologických perspektiv rozpracovává Swinton v knize John SWINTON - Harriet MOWATT, Practical Theology and Qualitative Research, 2. edition, London: SCM, 2016.

54 Srov. Hans G. GADAMER, Truth and Method, New York: Crossroad, 1989, s. 273, citováno podle SWINTON, Where is..., s. 82. 
a efektivně zahrnout vědcovu osobu do procesu intepretace, protože uznává, že je pro něj nemožné stát mimo ${ }^{\text {“ }}{ }^{55}$ Každé zkoumání je tak do určité míry autobiografické. Swinton dále argumentuje, že sociologové mohou samozřejmě zkoumat církev ze své perspektivy, vzájemná korelace perspektiv je žádoucí, většinou však po ní touží pouze teologové. To samé ostatně tvrdí i Van der Ven ve své kritice interdisciplinarity. ${ }^{56}$ Teolog však nemůže zkoumat církev, ve které žije, jako sociolog, nebyl by efektivní ani důvěryhodný. Může jí zkoumat jedině jako teolog, a to ve své interpretaci uznat. Výsledkem takového zkoumání budou jistě různé interpretace církevního prostředí, odvislé od denominace výzkumníka, což opět nebude v teologické tradici nic nového. Je s nimi však třeba vystoupit i před neteologické publikum, které je sice může odmítnout, ale mohou se pro něj stát i výzvou k vlastní reflexivitě.

\section{Závěr}

V tomto článku jsem se pokusila dokázat, že teologie potřebuje (mimo jiné) i empirické metody, aby mohla reflektovat lidskou víru ve světě a nepřímo pak také hovořit o Bohu. Teologie nemůže zůstat jen v horizontu existenciální racionality, ač z něj bezpochyby vychází, ale může (a měla by) bádat i v horizontu intelektuálním. Od vydání německé pokoncilní Handbuch der Pastoraltheologie se v praktické teologii o důležitosti využívání empirických metod teologií víceméně nepochybuje. Nepanuje však jednoznačný př́stup $\mathrm{k}$ aplikaci těchto metod. Van der Ven z různých př́stupů k empirickým technikám vytvořil paradigmatické modely. Můžeme se setkat s výzkumy multidisciplinárními, kdy se teologové pokouší teologicky interpretovat výsledky výzkumů sociálních věd, nebo interdisciplinárními, kdy dochází ke spolupráci mezi sociálními vědci a teology. Van der Ven však oba př́stupy považuje za problematické kvůli dominanci sociálních věd nad teologií a jako řešení navrhuje model intradisciplinární. V tomto modelu teolog adoptuje empirické metody a využívá jich jako teolog, což lze dobře realizovat v kvalitativních výzkumných technikách. Tyto techniky pak představují induktivní základ pro další zkoumání. To může být posléze i kvantitativní (deduktivní). V praktické teologii je důležité používat obě techniky. Potřebujeme zde jak hloubku, které lze dosáhnout jedině kvalitativně, tak reprezentativitu, kterou může zajistit kvantitativní př́stup. Van der Ven navrhuje metodu empiricko-teologického kruhu coby smíšenou techniku kombinující oba př́stupy. Specifickou kvalitativní metodu pak představuje etnografie, kde je pozorovatel př́mo účastný na pozorovaných jevech, a zdá se tak být ideálním nástrojem pro teology ke zkoumání církevního prostředí. Tato zkoumání pak mohou být pro teology impulsem pro revizi jejich vlastní teologie a vyžadují především reflexivitu. Může představovat výzvu i pro teologii systematickou. F. Štěch v souladu s P. Wardem tvrdí, že každá teologie je auto/theobiografická.

„Auto/theobiografická teologie není jen studium a kritická reflexe pramenů křestanské víry, je to také procházka krajinou, mytí nádobí, pomoc bližnímu, vodění dětí do školy, modlitba, sekání dřeva na zimu, radost $\mathrm{z}$ příchodu jara, pohlazení partnera, společná večeře s přáteli, návštěva koncertu či vynášení odpadkového koše. ${ }^{\text {“57 }}$

\footnotetext{
Srov. SWINTON, Where is..., s. 84.

6 Srov. VAN DER VEN, Practical theology..., s. 100.

57 ŠTĚCH, Co je teologie?, s. 20.
} 
Protože teologie je i život v současném světě, ve kterém se zjevuje Bůh. Domnívám se, že každá auto/theobiografie potřebuje i reflektovanou zkušenost církevního společenství, kterou lze získat v první řadě etnografickým přístupem. Jak se promění teologie, když se systematičtí teologové dřive, než zasednou za své psací stoly, vydají do společenství věrících ptát se na kvality jejich současných zkušeností s vírou ve světě, v němž žijí, a zúčastněně je pozorovat? Nebude pak teologie věrohodnější?

\title{
Možnosti využití empirických metod v (praktické) teologii
}

\begin{abstract}
Abstrakt
Teologie pracuje tradičně v jiném myšlenkovém horizontu než sociální vědy a použivá i odlišné metody. Přesto se po Il. vatikánském koncilu empirické metody postupně začínají využívat i v praktické teologii. Tento vývoj však není bez problémů a neexistuje pouze jediný správný způsob, jak s empirickými metodami v praktické teologii zacházet. Tento článek zkoumá možnosti využití empirických metod v teologii jak praktické, tak systematické. Jsou zde představeny a analyzovány modely vztahů teologie a empirických věd, které vytvořil Johannes van der Ven. Jeho model intradisciplinarity je zde považován za nejvhodnější model pro praktickou i systematickou teologii. $\mathrm{V}$ tomto modelu Ize využít různých empirických metod a technik. Jako ideální se však jeví zejména kvalitativní přístup, kde je důležitým výzkumným nástrojem sám vědec, což se nejžretelněji projevuje při práci etnografickou metodou. Tento přístup umožňuje teologovi zůstat teologem a využívat získaná data pro další teologickou reflexi.
\end{abstract}

Klíčová slova: praktická teologie, empirické metody, empirická teologie, intradisciplinarita, kvalitativní prístup, etnografie

\section{Kontakt}

\section{Mgr. Jana Šídlová}

Jihočeská univerzita v Českých Budějovicích

Teologická fakulta, Katedra pedagogiky

Kněžská 8, 37001 České Budějovice

sidloj00@tf.jcu.cz 